\title{
EFEKTIVITAS PELAYANAN DINAS PENANAMAN MODAL DAN PELAYANAN TERPADU SATU PINTU DALAM MENINGKATKAN INVESTASI DI KABUPATEN PANGKEP
}

\section{The Effectiveness of Investment Services And One Door Integrated Services (DPMPTSP) In Increasing Investment In Pangkep District}

\author{
Ince Ahmad Ismail ${ }^{1}$, Husain Hamka ${ }^{2}$, Syamsuddin Maldun ${ }^{2}$ \\ ${ }^{1}$ Dinas Penanaman Modal dan Pelayanan Terpadu Satu Pintu Kabupaten Pangkep \\ ${ }^{2}$ Program Studi Ilmu Administrasi Negara, Program Pascasarjana, Universitas Bosowa \\ Email: inceahmadismail@gmail.com
}

Diterima: 20 September 2021

Dipublikasikan: 23 Desember 2021

\begin{abstract}
ABSTRAK
Penelitian ini bertujuan untuk mengetahui dan menganalisis: 1) pengaruh secara parsial variabel independen (kualitas pelayanan) terhadap variabel dependen (tingkat investasi) di Dinas PMPTSP Kabupaten Pangkep. 2) pengaruh secara simultan variabel independen (kualitas pelayanan) terhadap variabel dependen (tingkat investasi) di Dinas PMPTSP Kabupaten Pangkep. Jenis penelitian yang akan digunakan dalam penelitian ini adalah penelitian kuantitatif dengan tipe studi kasus (Case Study). Populasi dalam penelitian ini sebanyak 55 orang, teknik pengambilan sampel dalam penelitian ini menggunakan Sampling Jenuh, sampel sebanyak 55 orang sebagai responden, teknik pengumpulan data menggunakan kuesioner dan dukumentasi. Teknik analisis data dalam penelitian ini menggunakan analisis deskriptif dan analisis inferensial. Hasil penelitian menunjukan bahwa pengaruh secara parsial dan simultan variabel independen (kualitas pelayanan) terhadap variabel dependen (tingkat investasi) di Dinas PMPTSP Kabupaten Pangkep terdapat kualitas pelayanan Dinas PMPTSP dalam meningkatkan investasi di Kabupaten Pangkep seperti kejelasan tujuan, kejelasan strategi, proses analisis kebijakan, perencanaan, penyusunan program, sarana dan prasarana, sistem pengawasan, dan sistem pengendalian.
\end{abstract}

Kata Kunci: Kualitas Pelayanan, Tingkat Investasi

\begin{abstract}
This study aims to determine and analyze: 1) the partial effect of the independent variable (service quality) on the dependent variable (investment level) in the PMPTSP Office of Pangkep Regency. 2) the simultaneous influence of the independent variable (service quality) on the dependent variable (investment level) in the PMPTSP Office of Pangkep Regency. The type of research that will be used in this research is quantitative research with case study type. The population in this study was 55 people, the sampling technique in this study used saturated sampling, a sample of 55 people as respondents, data collection techniques used questionnaires and documentation. The data analysis technique in this study used descriptive analysis and inferential analysis. The results showed that the partial and simultaneous influence of the independent variable (quality of service) on the dependent variable (level of investment) in the PMPTSP Office of Pangkep Regency there was the quality of service of the PMPTSP Service in increasing investment in Pangkep Regency such as clarity of objectives, clarity of strategy, policy analysis process, planning, program preparation, facilities and infrastructure, supervision system, and control system.
\end{abstract}

Keywords: Service Quality, Investment Level

This work is licensed under Creative Commons Attribution License 4.0 CC-BY International license

\section{PENDAHULUAN}

Bantuan publik pada hakekatnya adalah pengaturan administrasi ke wilayah setempat yang diidentikkan dengan pemenuhan kebutuhan wilayah setempat sebagai penduduk. Seperti yang diungkapkan oleh Sinambela (2008) dalam Alkadri et al., (2019) bahwa bantuan masyarakat juga dicirikan sebagai tindakan atau pengaturan latihan yang terjadi dalam kerjasama langsung antara individu dan orang lain atau mesin yang sebenarnya, dan memberikan loyalitas konsumen. . Penyelenggaraan administrasi publik adalah pekerjaan negara untuk memenuhi persyaratan esensial dan kebebasan sosial setiap penduduk untuk produk, administrasi, dan administrasi otoritatif yang diberikan oleh koperasi spesialis publik. Bentuk komitmen negara kepada warganya sesuai dengan amanat UUD 1945, secara khusus untuk memenuhi kebutuhan pokok setiap warga negara, salah satunya melalui penyelesaian administrasi publik secara layak dan produktif (Alkadri et al., 2019).

Dalam menawarkan jenis bantuan publik, perakitan mekanik harus memberikan administrasi yang sederhana, cepat dan tepat seperti kejelasan biaya, sistem dan lama administrasi. Dalam menawarkan jenis bantuan publik, otoritas pemerintah juga harus menerima keinginan daerah setempat, dengan alasan bahwa dalam perubahan waktu saat ini, publik Indonesia semakin mencela presentasi otoritas publik (Alkadri et al., 2019). 


\section{Maldun)}

Pasal 1 Angka 11 Peraturan Menteri Dalam Negara No 24 Tahun 2006 menarangkan kalau penyelenggaraan Pelayanan Terpadu Satu Pintu merupakan perpindahan perizinan serta nonperizinan yang siklus administrasinya dari sesi permohonan hingga dengan sesi penerbitan laporan dituntaskan dalam satu waktu. titik. Sedangkan itu, Pasal 11 No 12 Peraturan Menteri Dalam Negara No 24 Tahun 2006 menarangkan tentang pemerataan kewenangan, yang memiliki makna kalau penerapan izin yang dicoba terhadap pelakon usaha yang dicoba secara bertepatan mencakup lebih dari satu tipe. hibah yang disusun secara terkoordinasi serta simultan (Megantoro, 2019).

Pasal 26 Ayat 2 Undang- Undang No 25 Tahun 2007 tentang Penanaman Modal melaporkan kalau Pelayanan Terpadu Satu Pintu dicoba oleh organisasi ataupun kantor yang disetujui di wilayah spekulasi yang menemukan penugasan ataupun penunjukan kekuasaan dari yayasan ataupun kantor yang mempunyai wewenang serta tidak izin. kewenangan di tingkatan fokal. ataupun lagi organisasi ataupun lokal yang disetujui buat membagikan hibah serta non- perizinan di wilayah ataupun wilayah/ kota( Indonesia, 2007: 19). Setelah itu, pada ayat 3 tersebut disebutkan kalau pengaturan menimpa metode serta penerapan Pelayanan Terpadu Satu Pintu diatur dengan Peraturan Presiden, Indonesia (2007) pada( Pratiwi et angkatan laut (AL)., 2017). Oleh sebab itu, berarti buat bekerja pada watak administrasi dengan alibi terus menerus buat pengakuan administrasi publik yang luar biasa. Penyempurnaan watak administrasi publik dituntaskan secara luas serta terkoordinasi, baik di dalam ataupun di jarak jauh, wajib ditingkatkan serta memerlukan administrasi yang pas( Ismayanti, 2015).

Buat menolong kelancaran penyaluran dorongan publik yang luar biasa, otoritas publik sudah menetapkan Undang- Undang No 25 Tahun 2009 tentang Pelayanan Publik selaku landasan yang legal, sekalian membagikan kejelasan tentang pedoman penyelenggaraan pemerintahan. Mengingat Undang- Undang No 25 Tahun 2009 tentang Pelayanan Publik, negeri berkewajiban melayani tiap penduduk serta penunggu buat penuhi hak serta kebutuhan pokoknya dalam struktur penyelenggaraan pemerintahan yang ialah amanat Undang- Undang Dasar Negeri Republik Indonesia Tahun 1945. Luas administrasi negeri dalam Undang- Undang No 25 Tahun 2009 tentang Pelayanan Publik, meliputi administrasi produk publik, administrasi publik, serta administrasi manajerial. Pasal 6 ayat( 1) Peraturan Pemerintah No 96 Tahun 2012 tentang Penerapan Undang- Undang No 25 Tahun 2009 tentang Pelayanan Publik, ditegaskan kalau penyelenggaraan peraturan merupakan penyelenggaraan oleh koperasi spesialis terbuka yang menciptakan bermacam tipe laporan yang benar yang diperlukan oleh wilayah.

Penyelenggaraan administrasi sebagaimana disinggung dalam Peraturan Pemerintah Nomor 96 Tahun 2012 tentang Pelaksanaan Undang-Undang Nomor 25 Tahun 2009 tentang Pelayanan Publik meliputi kegiatan kewenangan pemerintah dan kegiatan pengaturan oleh lembaga swadaya masyarakat yang diperlukan oleh negara dan diarahkan pada peraturan perundangundangan. Kegiatan pengaturan oleh organisasi pemerintah diselesaikan sebagai administrasi untuk memberikan catatan melalui otorisasi dan non-perizinan. Otorisasi adalah segala bentuk pengesahan yang diberikan oleh badan publik dan pemerintah daerah yang memiliki tenaga ahli sesuai dengan pengaturan peraturan perundang-undangan, sedangkan non-perizinan pada umumnya adalah jenis kemudahan administrasi, kantor keuangan, dan data sesuai dengan pengaturan undangundang. dan pedoman.

Menurut Sinambela (2011) pelayanan publik merupakan pemenuhan keinginan dan kebutuhan masyarakat oleh penyelenggara negara dan negara didirikan oleh publik dengan tujuan agar dapat meningkatkan kesejahteraan masyarakat. Alasan administrasi publik adalah untuk memenuhi daerah sebagai klien administrasi (Sinambela, 2011). Pemenuhan ini dapat dicapai dengan menawarkan jenis bantuan yang berkualitas atau bantuan yang brilian yang tercermin dalam keterusterangan, khususnya administrasi yang terbuka, sederhana dan tersedia untuk semua kalangan yang membutuhkan dan diberikan secara cukup dan mudah dipahami (Sinambela, 2011). Tanggung jawab adalah bantuan yang dapat diwakilkan sesuai dengan pengaturan dalam undang-undang. Kontingen, adalah administrasi khusus yang sesuai dengan kondisi dan kemampuan koperasi spesialis dan penerima manfaat dengan tetap berpegang pada standar kecakapan dan kecukupan. Partisipatif, khususnya manfaat yang dapat mendukung investasi daerah dalam penyelenggaraan administrasi publik dengan mempertimbangkan tujuan, persyaratan, dan asumsi daerah. Hak yang setara, khususnya manfaat yang tidak membedakan sejauh mana perspektif apapun, terutama kebangsaan, ras, agama, golongan, kedudukan sosial dan lain-lain. Keseimbangan hak dan komitmen, khususnya administrasi yang memikirkan bagian dari kesetaraan antara pemasok dan penerima manfaat dari administrasi publik (Susianto, 2016).

Mengingat kemungkinan masalah yang dilihat oleh daerah sebagai klien administrasi dengan tujuan akhir untuk mengatasi kekurangan yang berbeda dan mengharapkan kekurangan dalam sifat administrasi publik, administrasi di kantor spekulasi dan bantuan terpadu satu atap membuat penerbitan izin waktu lebih terbatas. Penjelasannya, dengan organisasi berbasis inovasi data, cukup memasukkan informasi satu kali dan organisasi harus memungkinkan pada saat yang bersamaan. Yang berencana untuk lebih mengembangkan lingkungan usaha untuk memberdayakan pengembangan moneter daerah (Yudhisthira dan Niswah, 2019). 


\section{METODE}

Jenis penelitian yang akan digunakan adalah penelitian kuantitatif dengan tipe Studi Kasus (Case Study). Populasi dalam penelitian ini adalah keseluruhan pegawai yang bekerja di Dinas PMPTSP Kabupaten Pangkep sebanyak 55 orang. Teknik pengambilan Sampel dalam penelitian ini menggunakan Sampling Jenuh, Sampling Jenuh adalah teknik menentukan sampel bila semua anggota populasi digunakan sebagai sampel (Sugiyono, 2012). Jumlah Sampel dalam penelitian ini adalah keseluruhan pegawai yang bekerja di Dinas PMPTSP Kabupaten Pangkep sebanyak 55 orang.

Definisi operasional adalah maksud peneliti dalam mendefenisikan setiap variable yang digunakan dalam tahap penelitian (Sugiyono, 2012). Dalam penelitian ini, variabel independen adalah Kejelasan tujuan (X1), Kejelasan strategi (X2), Proses analisis kebijaksanaan (X3), Perencanaan (X4), Penyusunan program (X5), Sarana dan prasarana (X6), Sistem pengawasan (X7), Sistem pengendalian (X8). Variabel dependen merupakan variabel yang dipengaruhi atau yang menjadi akibat, karena adanya variabel independen (Sugiyono, 2012). Pada penelitian ini terdapat variabel satu variabel dependen yaitu tingkat investasi (Y). Teknik pengumpulan data yang dilakukan dalam penelitian ini adalah angket atau kuesioner dan dokumentasi. Teknik analisis data analisis deskriptif dan analisis statistik inferensial.

\section{HASIL DAN PEMBAHASAN}

\section{Hasil Perhitungan Statistik Deskriptif}

Berdasarkan hasil penelitian menunjukan bahwa untuk variabel kejelasan tujuan (X1) diperoleh nilai mean 7,64 dengan standar deviasi 2,475, variabel kejelasan strategi (X2) diperoleh nilai mea n 8,02 dengan standar deviasi 2,400, variabel proses analisis kebijakan (X3) diperoleh nilai mean 8,75 dengan standar deviasi 1,946, variabel perencanaan (X4) diperoleh nilai mean 7,15 dengan standar deviasi 1,890 , variabel penyusunan program (X5) diperoleh nilai mean 7,02 dengan standar deviasi 2,321, variabel sarana dan prasarana (X6) diperoleh nilai mean 7,78 dengan standar deviasi 2,608, variabel sistem pengawasan (X7) diperoleh nilai mean 7,20 dengan standar deviasi 1,966, variabel sistem pengendalian (X8) diperoleh nilai mean 8,44 dengan standar deviasi 2,217 dan variabel tingkat investasi (Y) diperoleh nilai mean 42,80 dengan standar deviasi 11,503. Rata-rata skor yang diperoleh adalah sebesar 88,44 dengan standar deviasi 12,55. Dari hasil perhitungan statistik deskriptif tersebut diketahui bahwa untuk seluruh variabel diperoleh nilai standar deviasi yang lebih kecil dari nilai rata-rata skor. Hal ini mengindikasikan bahwa nilai rata-rata dapat digunakan sebagai representasi keseluruhan data.

Hasil pengujian normalitas data dengan statistik Kolmogorov-Sm irnov diperoleh nilai p (Sig.) untuk variabel kejelasan tujuan (X1) sebesar 0,386, variabel kejelasan strategi (X2) sebesar 0,679, variabel proses analisis kebijakan (X3) sebesar 0,083, variabel perencanaan (X4) sebesar 0,368, variabel penyusunan program (X5) sebesar 0,791, variabel sarana dan prasarana (X6) sebesar 0,724, variabel sistem pengawasan (X7) sebesar 0,305, variabel sistem pengendalian (X8) sebesar 0,104 dan variabel tingkat investasi (Y) sebesar 0,923 . Nilai $\mathrm{p}$ dari variabel-variabel tersebut lebih dari 0,05 , hal tersebut menunjukkan bahwa data dari variabelvariabel tersebut berdistribusi normal.

Untuk variabel kejelasan tujuan (X1) diperoleh nilai Tolerance 0,104 dan nilai VIF 8,600, untuk variabel kejelasan strategi (X2) diperoleh nilai Tolerance 0,036 dan nilai VIF 7,698, untuk variabel proses analisis kebijakan (X3) diperoleh nilai Tolerance 0,153 dan nilai VIF 6,541, untuk variabel perencanaan (X4) diperoleh nilai Tolerance 0,090 dan nilai VIF 8,119, untuk variabel penyusunan program (X5) diperoleh nilai Tolerance 0,052 dan nilai VIF 5,162, untuk variabel sarana dan prasarana (X6) diperoleh nilai Tolerance 0,039 dan nilai VIF 6,903, untuk variabel sistem pengawasan (X7) diperoleh nilai Tolerance 0,133 dan nilai VIF 6,545 dan untuk variabel sistem pengendalian (X8) diperoleh nilai Tolerance 0,104 dan nilai VIF 6,570. Dari hasil tersebut diketahui bahwa untuk variabel $\mathrm{X} 1, \mathrm{X} 3, \mathrm{X} 7$, dan $\mathrm{X} 8$ diperoleh nilai Tolerance lebih dari 0,10 dan nilai VIF kurang dari 10,00 sementara untuk variabel X2, X4, X5, dan X6 diperoleh nilai Tolerance kurang dari 0,10 dan nilai VIF lebih dari 10,00. Hal tersebut berarti bahwa variabel X1, X3, X7, dan $\mathrm{X} 8$ tidak terjadi multikolinearitas dan variabel $\mathrm{X} 2$, X4, X5, dan X6 terjadi multikolinearitas. Medel regresi yang baik adalah tidak terjadi heteroksedastisitas.Untuk menguji heteroksedastisitas dengan melihat grafik scatterplot, jika pada hasil regresi grafik scatterplot membentuk pola tertentu yang teratur seperti bergelombang, melebar kemudian menyempit, maka terjadi heteroksedastisitas.

Hasil pengujian autokorelasi bahwa nilai DW (Durbin-Watson) yang diperoleh adalah sebesar 1,958. Selanjutnya dicari nilai d tabel dimana diketahui jumlah variabel atau $\mathrm{k}=9$ dan banyaknya sampel atau $\mathrm{n}=55$. Berdasarkan tabel Durbin Watson diperoleh nilai $\mathrm{dl}=1,253$ dan nilai $\mathrm{du}=1,909$ sehingga dapat dihitung nilai 4-du $=4-1,909=2,091$. Kriteria tidak adanya autokorelasi terpenuhi apabila $\mathrm{du}<\mathrm{d}<(4-\mathrm{du})$. Berdasarkan kriteria tersebut, nilai 1,958 (d) lebih dari nilai 1,909 (du) dan kurang dari nilai 2,091 (4-du) atau dapat ditulis $1,909<1,958<2,091$. Dengan demikian dapat disimpulkan bahwa dalam model regresi linier yang digunakan, tidak terjadi autokorelasi.

\section{Hasil Analisis Regresi Linear Multipel}

Diperoleh nilai konstanta atau $a=2,411$, nilai koefisien regresi untuk variabel $\mathrm{X}_{1}$ atau $b_{1}=0.597$, nilai koefisien regresi untuk variabel $\mathrm{X}_{2}$ atau $b_{2}=0.917$, nilai koefisien regresi untuk variabel $\mathrm{X}_{3}$ atau $b_{3}=0,488$, nilai koefisien regresi untuk variabel $\mathrm{X}_{4}$ atau $b_{4}=0,676$, nilai koefisien regresi untuk variabel $\mathrm{X}_{5}$ atau $b_{5}=0,719$, nilai 


\section{Maldun)}

koefisien regresi untuk variabel $\mathrm{X}_{6}$ atau $b_{6}=0,837$, nilai

koefisien regresi untuk variabel $\mathrm{X}_{7}$ atau $b_{7}=0,493$, nilai

koefisien regresi untuk variabel $\mathrm{X}_{8}$ atau $b_{8}=0,506$.

Berdasarkan nilai-nilai tersebut, maka persamaan regresinya yaitu: $Y=2,411+0,597 X_{1}+0,917 X_{2}+$ $0,488 X_{3}+0,676 X_{4}+0,719 X_{5}+0,837 X_{6}+0,493 X_{7}+$ $0,506 X_{8}$.

a. Pengaruh Parsial Variabel Independen terhadap Variabel Dependen

1) Pengaru h Kejelasan Tujuan (X1) terhadap Tingkat Investasi (Y).

Berdasarkan tabel 4.6, hasil pengujian hipotesis untuk pengaruh kejelasan tujuan (X1) terhadap tingkat investasi (Y) diperoleh nilai p (Sig.) $=0,008$. Nilai tersebut kurang dari 0,05 sehingga H0 ditolak dan H1 diterima. Dengan demikian dapat disimpulkan bahwa terdapat pengaruh kejelasan tujuan (X1) terhadap tingkat investasi (Y).

2) Pengaruh Kejelasan Strategi (X2) terhadap Tingkat Investasi (Y)

Berdasarkan tabel 4.6, hasil pengujian hipotesis untuk pengaruh kejelasan strategi (X2) terhadap tingkat investasi (Y) diperoleh nilai p (Sig.) $=0,020$. Nilai tersebut kurang dari 0,05 sehingga $\mathrm{H} 0$ ditolak dan H1 diterima. Dengan demikian dapat disimpulkan bahwa terdapat pengaruh kejelasan strategi (X2) terhadap tingkat investasi (Y).

3) Pengaruh Proses Analisis Kebijakan (X3) terhadap Tingkat Investasi (Y)

Berdasarkan tabel 4.6, hasil pengujian hipotesis untuk pengaruh proses analisis kebijakan (X3) terhadap tingkat investasi (Y) diperoleh nilai p (Sig.) $=0,037$. Nilai tersebut kurang dari 0,05 sehingga H0 ditolak dan $\mathrm{H} 1$ diterima. Dengan demikian dapat disimpulkan bahwa terdapat pengaruh proses analisis kebijakan (X3) terhadap tingkat investasi (Y).

4) Pengaruh Perencanaan (X4) terhadap Tingkat Investasi (Y)

Berdasarkan tabel 4.6, hasil pengujian hipotesis untuk pengaruh perencanaan (X4) terhadap tingkat investasi (Y) diperoleh nilai $\mathrm{p}($ Sig. $)=0,032$. Nilai tersebut kurang dari 0,05 sehingga H0 ditolak dan H1 diterima. Dengan demikian dapat disimpulkan bahwa terdapat pengaruh perencanaan (X4) terhadap tingkat investasi (Y).

5) Pengaruh Penyusunan Program (X5) terhadap Tingkat Investasi (Y)

Berdasarkan tabel 4.6, hasil pengujian hipotesis untuk pengaruh penyusunan program (X5) terhadap tingkat investasi $(\mathrm{Y})$ diperoleh nilai $\mathrm{p}($ Sig. $)=0,033$. Nilai tersebut kurang dari 0,05 sehingga H0 ditolak dan H1 diterima. Dengan demikian dapat disimpulkan bahwa terdapat pengaruh penyusunan program (X5) terhadap tingkat investasi (Y).

6) Pengaruh Sarana dan Prasarana (X6) terhadap Tingkat Investasi (Y)
Berdasarkan tabel 4.6, hasil pengujian hipotesis untuk pengaruh sarana dan prasarana (X6) terhadap tingkat investasi (Y) diperoleh nilai $\mathrm{p}($ Sig. $)=0,017$. Nilai tersebut kurang dari 0,05 sehingga H0 ditolak dan H1 diterima. Dengan demikian dapat disimpulkan bahwa terdapat pengaruh sarana dan prasarana (X6) terhadap tingkat investasi (Y).

7) Pengaruh Sistem Pengawasan (X7) terhadap Tingkat Investasi (Y)

Berdasarkan tabel 4.6, hasil pengujian hipotesis untuk sistem pengawasan (X7) terhadap tingkat investasi (Y) diperoleh nilai $\mathrm{p}$ (Sig.) $=0,048$. Nilai tersebut kurang dari 0,05 sehingga $\mathrm{H} 0$ ditolak dan H1 diterima. Dengan demikian dapat disimpulkan bahwa terdapat pengaruh sistem pengawasan (X7) terhadap tingkat investasi (Y).

8) Pengaruh Sistem Pengendalian (X8) terhadap Tingkat Investasi (Y).

Berdasarkan tabel 4.6, hasil pengujian hipotesis untuk sistem pengendalian (X8) terhadap tingkat investasi (Y) diperoleh nilai $\mathrm{p}$ (Sig.) $=0,042$. Nilai tersebut kurang dari 0,05 sehingga $\mathrm{H} 0$ ditolak dan H1 diterima. Dengan demikian dapat disimpulkan bahwa terdapat pengaruh sistem pengendalian (X8) terhadap tingkat investasi (Y).

b. Pengaruh Simultan Variabel Independen terhadap Variabel Dependen

Hasil pengujian hipotesis pengaruh simultan variabel independen terhadap variabel dependen tampak bahwa nilai $\mathrm{p}$ (Sig.) $=0,000$. Nilai tersebut kurang dari 0,05 sehingga $\mathrm{H} 0$ ditolak dan $\mathrm{H} 1$ diterima yang berarti bahwa terdapat pengaruh kejelasan tujuan (X1), kejelasan strategi (X2), proses analisis kebijakan (X3), perencanaan (X4), penyusunan program (X5), sarana dan prasarana (X6), sistem pengawasan (X7), dan sistem pengendalian (X8) secara bersama-sama terhadap tingkat investasi (Y).

\section{Kejelasan Tujuan (X1)}

Berdasarkan hasil penelitian menunjukan bahwa Nilai koefisien (X1) sebesar 0,597 menunjukkan bahwa apabila nilai kejelasan tujuan (X1) bertambah satu maka tingkat investasi (Y) bertambah 0,597 dengan asumsi X2, X3, X4, X5, X6, X7, dan X8 tetap. Untuk hasil pengujian hipotesis untuk pengaruh kejelasan tujuan (X1) terhadap tingkat investasi $(Y)$ diperoleh nilai $\mathrm{p}(\mathrm{Sig}$.) $=0,008$. Nilai tersebut kurang dari 0,05 sehingga $\mathrm{H} 0$ ditolak dan $\mathrm{H} 1$ diterima. Dengan demikian dapat disimpulkan bahwa terdapat pengaruh kejelasan tujuan (X1) terhadap tingkat investasi (Y). Hasil tersebut menunjukan bahwa pegawai dalam melaksanakan tugasnya dapat mencapai target dan sasaran yang terarah sehingga tujuan Dinas PMPTSP Kabupaten Pangkep dapat tercapai.

Mengingat konsekuensi dari penyelidikan, para ilmuwan dapat membedah kejelasan tujuan di Kantor PMPTSP dengan tujuan akhir untuk mencapai tujuan dan fokus dari pameran Pangkep Rule Venture dan Kantor Administrasi Terpadu Satu Pintu (DPMPTSP), penting untuk mengarahkan pemeriksaan yang jauh dan 
terkoordinasi dari komponen alam termasuk isu-isu penting yang dapat mempengaruhi pencapaian tujuan dan tujuan perbaikan. Isu-isu esensial adalah sebagai berikut, 1. Kemajuan di bidang administrasi, keterampilan aset manusia, dan aksesibilitas kerangka kerja dalam mendukung pelaksanaan kewajiban dan unsur-unsur perakitan mekanik Ventura dan Satu Pintu (DPMPTSP) Pangkep Rezim. Unsur-unsur SKPD DMPTSP yang terus melakukan penyempurnaan sebagai substansi bebas di bidang administrasi perizinan usaha dan usaha. Berbagai penanda eksekusi yang telah diperoleh termasuk kecepatan dan kemudahan administrasi PMA dan PMDN melalui penyusunan kerangka kerja standar dan dukungan untuk fondasi inovasi data dan administrasi record get. 2 . Adanya Surat Pernyataan Nomor 97 Tahun 2014 tentang PTSP di Bidang Spekulasi dapat dijadikan sebagai salah satu sumber perspektif untuk lebih mengembangkan kualitas pendampingan dengan mitra. 3. Keadaan potensi dan pintu terbuka usaha dalam Peraturan Pangkep yang sangat besar dapat memberdayakan perkembangan spekulasi, baik PMA maupun PMDN. 4. Perkembangan moneter Indonesia yang tinggi dan pembengkakan yang stabil dapat mendorong pengembangan usaha di Rezim Pangkep. 5. Bundel strategi yang diberikan oleh otoritas publik oleh otoritas publik. 6. Mengerjakan sifat SDM.

Hal ini sesuai dengan Mahmudi (2007:84) dalam Prijono dkk (2018:54) kecukupan adalah keterkaitan antara hasil dan tujuan. Semakin menonjol komitmen hasil untuk pencapaian tujuan, semakin kuat asosiasi, program, atau tindakan.

\section{Kejelasan Strategi $(X 2)$}

Nilai koefisien X2 sebesar 0,917 menunjukkan bahwa apabila nilai kejelasan strategi (X2) bertambah satu maka tingkat investasi (Y) bertambah 0,917 dengan asumsi X1, X3, X4, X5, X6, X7, dan X8 tetap. Untuk hasil pengujian hipotesis untuk pengaruh kejelasan strategi (X2) terhadap tingkat investasi (Y) diperoleh nilai $\mathrm{p}$ (Sig.) $=0,020$. Nilai tersebut kurang dari 0,05 sehingga $\mathrm{H} 0$ ditolak dan $\mathrm{H} 1$ diterima. Dengan demikian dapat disimpulkan bahwa terdapat pengaruh kejelasan strategi (X2) terhadap tingkat investasi (Y). Hasil tersebut menunjukan bahwa penentuan cara, jalan atau upaya yang harus dilakukakan dalam mencapai semua tujuan yang sudah ditetapkan agar para implementer tidak tersesat dalam pencapaian tujuan organisasi. Seperti penentuan wawasan waktu, dampak dan pemusatan upaya.

Dari hasil-hasil ini, para ilmuwan dapat menyelidiki kejelasan prosedur untuk melakukan tugas-tugas ini, Kantor Administrasi Ventura dan One Stop Incorporated memiliki kapasitas sebagai berikut: a. Penyusunan rencana pokok dan rencana kerja dan rencana keuangan DPMPTSP; B. pelaksanaan rencana vital dan laporan pelaksanaan belanja DPMPTSP; C. perincian strategi, aturan, dan asas-asas khusus pelaksanaan DPMPTSP sesuai dengan pengaturan peraturan perundang-undangan; D. Pemeriksaan, pembuatan, pengendalian dan pembinaan, pemeriksaan dan penilaian pelaksanaan
DPMPTSP; e. Pengakuan dan eksplorasi / penilaian catatan pemanfaatan untuk otorisasi dan non-perizinan seperti laporan peraturan sesuai dengan spesialis masingmasing; F. Eksekusi eksplorasi khusus/pengujian aktual aplikasi otorisasi dan non-perizinan seperti arsip peraturan; G. Menandai dan mengirimkan arsip hibah, non-lisensi, dan peraturan sesuai dengan spesialisnya yang terpisah; H. Pengurus arsip perijinan, nonhibah dan peraturan sesuai kewenangannya; I. Jaminan dan beban persetujuan atas penyalahgunaan lisensi dan non-izin seperti arsip peraturan sesuai dengan spesialisnya yang terpisah; J. Pelaksanaan penyempurnaan DPMPTSP; k. pelaksana kerangka inovasi data untuk pelaksanaan DPMPTSP; 1. Penatausahaan dan penyelesaian keberatan/keluhan, surat menyurat publik atas pelaksanaan DPMPTSP dan bantuan hukum; $\mathrm{M}$. Penatausahaan dan penyelesaian keberatan/keluhan administrasi dapat diselesaikan di DPMPTSP; n. Para pelaksana fakultas, keuangan, produk DPMP'TSP; Hai. Organisasi dan tata graha pengurus DPMPTSP; $P$. DPMPTSP inovasi, informasi dan data para pelaksana; dan q. Mengumumkan dan mempertanggungjawabkan pelaksanaan kewajiban dan unsur DPMPTSP.

Hal ini sesuai dengan hasil pemeriksaan Pratama (2018: 654). Kecukupan adalah pemenuhan pekerjaan sejauh mencapai tujuan serta sejauh idealitas dalam mencapai tujuan tersebut. Dari penilaian di atas, cenderung disimpulkan bahwa kelangsungan hidup diidentikkan dengan masalah waktu. Suatu tindakan dikatakan ampuh jika gerakan tersebut selesai secara efektif sesuai dengan waktu yang telah ditentukan atau secara keseluruhan sesuai jadwal (Pratama, 2018: 654).

Proses analisis kebijaksanaan (X3)

Nilai koefisien X3 sebesar 0,488 menunjukkan bahwa apabila nilai proses analisis kebijakan (X3) bertambah satu maka tingkat investasi (Y) bertambah 0,488 dengan asumsi X1, X2, X4, X5, X6, X7, dan X8 tetap. Untuk hasil pengujian hipotesis untuk pengaruh proses analisis kebijakan (X3) terhadap tingkat investasi (Y) diperoleh nilai $\mathrm{p}$ (Sig.) $=0,037$. Nilai tersebut kurang dari 0,05 sehingga H0 ditolak dan H1 diterima. Dengan demikian dapat disimpulkan bahwa terdapat pengaruh proses analisis kebijakan (X3) terhadap tingkat investasi (Y). Hasil tersebut menunjukan bawah tujuan yang hendak dicapai dan strategi yang telah ditetapkan artinya kebijakan yang sudah dirumuskan tersebut mampu menjembatani tujuan-tujuan dengan usaha-usaha pelaksanaan kegiatan operasional.

Berdasarkan hasil penelitian maka peneliti dapat menganalisis tentang proses analisis kebijaksanaan di Dinas PMPTSP dalam terpenuhinya sifat pemerataan pemberian, penghiburan, kesesuaian dan pemenuhan dalam mendapatkan administrasi oleh majelis mekanik bantuan terpadu satu pintu, khususnya sebagai berikut: Pelaksanaan pemberian wewenang/non perizinan dengan tingkat kejelasan dan kepastian kepada pemerintah daerah. daerah. Aksesibilitas grup eksplorasi dan 
Maldun)

penilaian aktual aplikasi otorisasi dan non-perizinan (TABG). Catatan Laporan Moneter DPMPTSP

Hal ini sesuai dengan pandangan Steers bahwa "Kecukupan adalah ruang lingkup upaya suatu program sebagai kerangka kerja dengan aset tertentu dan bermaksud untuk memenuhi tujuan dan sarananya tanpa merusak sarana dan aset dan tanpa memeras pelaksanaannya.

\section{Perencanaan (X4)}

Nilai koefisien X4 sebesar 0,676 menunjukkan bahwa apabila nilai perencanaan (X4) bertambah satu maka tingkat investasi (Y) bertambah 0,676 dengan asumsi X1, X2, X3, X5, X6, X7, dan X8 tetap. Untuk hasil pengujian hipotesis untuk pengaruh perencanaan (X4) terhadap tingkat investasi (Y) diperoleh nilai $\mathrm{p}$ (Sig.) $=0,032$. Nilai tersebut kurang dari 0,05 sehingga $\mathrm{H} 0$ ditolak dan H1 diterima. Dengan demikian dapat disimpulkan bahwa terdapat pengaruh perencanaan (X4) terhadap tingkat investasi (Y). Hasil tersebut menunjukan bawah pengambilan keputusan yang dilakukan oleh Dinas PMPTSP Kabupaten Pangkep untuk mengembangkan program atau kegiatan dimasa yang akan datang sangat tepat.

Hal tersebut sejalan dengan Peraturan Menteri Dalam Negeri Nomor 24 tahun 2006 tentang Pedoman Penyelenggaraan Pelayanan Terpadu Satu Pintu (PTSP). Peraturan menteri ini sebagai acuan bagi pemerintah daerah untuk membangun sistem perizinan satu pintu, artinya dengan sistem yang memangkas sistem birokrasi yang berbelit belit.

\section{Penyusunan Program (X5)}

Nilai koefisien X5 sebesar 0,719 menunjukkan bahwa apabila nilai penyusunan program (X5) bertambah satu maka tingkat investasi (Y) bertambah 0,719 dengan asumsi X1, X2, X3, X4, X6, X7, dan X8 tetap. Untuk hasil pengujian hipotesis untuk pengaruh penyusunan program (X5) terhadap tingkat investasi (Y) diperoleh nilai $\mathrm{p}$ (Sig.) $=0,033$. Nilai tersebut kurang dari 0,05 sehingga H0 ditolak dan H1 diterima. Dengan demikian dapat disimpulkan bahwa terdapat pengaruh penyusunan program (X5) terhadap tingkat investasi (Y). hasil tersebut menunjukan bahwa menyusun rencana yang baik masih perlu dijabarkan dalam program-program pelaksanaan yang tetap sebab apabila tidak, para pelaksana akan kurang memiliki pedoman untuk bertindak dan bekerja.

Berasarkan hasil penelitian maka peneliti dapat menganalisis bahwa penyusunan program sesuai dengan tugas dan fungsi Dinas PMPTSP Kabupaten Pangkep, Program yang dilaksanakan bertujuan untuk memperluas pengakuan dan perampasan spekulasi melalui pembentukan lingkungan yang menguntungkan bagi dunia usaha untuk membantu memperluas jumlah dan sifat perekonomian Rezim Pangkep. Substansi dasar dari upaya untuk memperluas spekulasi adalah sebagai latihan: mengatur dan kemungkinan pergantian peristiwa, pengembangan usaha, administrasi perizinan usaha, manajemen dan kontrol serta kesiapan jaringan pendukung emosional berbasis elektronik. Mengingat Perda Nomor 1 Tahun 2012 tentang Penataan Ruang Wilayah, kerangka komunitas gerakan lokal Rezim Pangkep diisolasi menjadi 3 tempat aksi, yaitu habitat aksi esensial, opsional, dan tersier.

Berdasarkan Tata Ruang Wilayah (RTRW) ada beberapa faktor yang menghambat dan memberatkan administrasi Tata Usaha dan Tata Tertib Satu Pintu (DPMPTSP) yang mempengaruhi penyelenggaraan SKPD adalah sebagai berikut, Kesediaan untuk menyetujui pedoman yang digambarkan oleh otoritas publik, seperti memperoleh hibah bangunan ( IMB) sebelum membangun struktur. Keinginan daerah untuk membuat dan mengerjakan kantor dan kerangka kota. Keinginan para pendukung keuangan untuk menyelamatkan tanah untuk pengembangan kantor dan yayasan metropolitan. Kemampuan pendukung keuangan yang mungkin untuk secara tepat mengawasi dan mengikuti yayasan dan kantor yang diberikan oleh otoritas publik. memberikan hibah pemanfaatan ruang sesuai dengan tata ruang, pedoman penyusunan, dan asas paling tidak membantu di bidang penataan ruang; Penggunaan ruang memungkinkan yang saat ini tidak sesuai karena perubahan tata ruang wilayah

Hal ini juga sesuai dengan Pedoman Pendeta Rumah Tangga Nomor 24 Tahun 2006 tentang Tata Tertib Penyelenggaraan Pelayanan Terpadu Satu Pintu, dan Pedoman Pendeta Rumah Isu Nomor 20 Tahun 2008 tentang Tata Tertib Berserikat dan Tata Kerja Kesatuan Kewenangan Terkoordinasi di Daerah yang diamanatkan oleh Undang-undang Nomor 41 Tahun 2007 tentang Persatuan Kontrasepsi Provinsi, suatu majelis mekanik teritorial untuk menyelenggarakan pemerintahan berbadan hukum satu atap di wilayah Indonesia, baik Daerah maupun Kabupaten/Kota adalah dibingkai. Kemudian lagi, Undang-Undang Nomor 25 Tahun 2007 tentang Usaha, khususnya Pasal 25 dan Pasal 26 antara lain menyatakan bahwa suatu organisasi spekulasi yang akan melakukan kegiatan usaha harus mendapatkan izin sesuai pengaturan yang berlaku dari pejabat yang berwenang, melalui Bantuan Terpadu Satu Pintu (PTSP).

\section{Sarana dan Prasarana (X6)}

Nilai koefisien X6 sebesar 0,837 menunjukkan bahwa apabila nilai sarana dan prasarana (X6) bertambah satu maka tingkat investasi (Y) bertambah 0,837 dengan asumsi X1, X2, X3, X4, X5, X7, dan X8 tetap. Untuk hasil pengujian hipotesis untuk pengaruh sarana dan prasarana (X6) terhadap tingkat investasi (Y) diperoleh nilai $\mathrm{p}$ (Sig.) $=0,017$. Nilai tersebut kurang dari 0,05 sehingga H0 ditolak dan H1 diterima. Dengan demikian dapat disimpulkan bahwa terdapat pengaruh sarana dan prasarana (X6) terhadap tingkat investasi (Y). Hasil tersebut menynjukan bahwa tersediannya sarana dan prasarana kerja, peralatan kerja dan pendukung lainnya yang memadai termasuk penyediaan sarana teknologi telekomunikasi dan informatika (telematika). 
Berdasarkan hasil penelitian mengenai sarana dan prasarana maka peneliti dapat meganalisis bahwa aset yang dipergunakan oleh Dinas PMPTSP Kabupaten pangkep sebagai sarana dan prasarana kerja merupakan aset daerah dengan status kekayaan daerah yang tidak dapat dipisahkan. Pengelolaan aset atau sarana dan prasarana kerja dilaksanakan sesuai dengan ketentuan peraturan perundang-undangan. Standarisasi peralatan kerja menjadi acuan pengadaan peralatan kerja Dinas PMPTSP Kabupaten Pangkep.

Hal tersebut juga sejalan dengan Richard mengutip pendapat dari Basil Georgopoulos dan Arnold Tannenbaum yang berargumentasi bahwa ukuran efektivitas harus didasarkan pada sarana dan tujuan organisasi, dari pada berdasarkan pada kriteria yang berasal dari luar.

Menurut Siagian (2004:151) adalah pemanfaatan sumber daya, dana, sarana dan prasarana dalam jumlah tertentu yang secara sadar ditetapkan sebelumnya untuk menghasilkan sejumlah barang atau jasa dengan mutu tertentu tepat pada waktunya

\section{Sistem pengawasan $(X 7)$}

Nilai koefisien X7 sebesar 0,493 menunjukkan bahwa apabila nilai sistem pengawasan (X7) bertambah satu maka tingkat investasi (Y) bertambah 0,493 dengan asumsi X1, X2, X3, X4, X5, X6, dan X8 tetap. Untuk hasil pengujian hipotesis untuk sistem pengawasan (X7) terhadap tingkat investasi $(\mathrm{Y})$ diperoleh nilai $\mathrm{p}($ Sig. $)=$ 0,048 . Nilai tersebut kurang dari 0,05 sehingga $\mathrm{H} 0$ ditolak dan H1 diterima. Dengan demikian dapat disimpulkan bahwa terdapat pengaruh sistem pengawasan (X7) terhadap tingkat investasi $(\mathrm{Y})$. hasil tersebut menunjukan bahwa pengawasan ini diperlukan untuk mengatur dan mencegah kemungkinan - kemungkinan adanya penyimpangan dalam pelaksanaan suatu program atau kegiatan, sehingga tujuan Dinas PMPTSP Kabupaten Pangkep dapat tercapai.

Buat membagikan pelayanan yang transparan, perlakuan yang sama, gampang, efektif, kilat, berkeadilan, akuntabilitas, dan kepastian hukum, dibutuhkan pelayanan dibidang penanaman modal tersebut, baik pelayanan perizinan ataupun non perizinan yang dilaksanakan secara terpadu satu pintu, yang diucap dengan Pelayanan Terpadu Satu Pintu( PTSP) di Bidang Penanaman Modal, sebagaimana amanatkan dalam Undang- Undang No 25 Tahun 2007 tentang Penanaman Modal, Peraturan Presiden No 27 Tahun 2009 tentang Pelayanan Terpadu Satu Pintu di Bidang Penanaman Modal, Peraturan Kepala Tubuh Koordinasi Penanaman Modal No 11 Tahun 2009 tentang Tata Metode Penerapan, Pembinaan, serta Pelaporan Pelayanan Terpadu Satu Pintu di Bidang Penanaman Modal, serta Peraturan Kepala Tubuh Koordinasi Penanaman Modal No 12 Tahun 2009 tentang Pedoman serta Tata Metode Permohonan Penanaman Modal.

Bersumber pada hasil riset hingga periset dapa menganalisis tentang sistem pengawasan Dinas PMPTS kabupaten Pangkep kalau industri yang jadi sasaran peninjauan pemakaian perizinan. Realisasi jumlah industri yang ditinjau. Maksudnya realisasi ini cuma menggapai 55 persen dari sasaran yang sudah diresmikan.

Selain itu, target kinerja program yang lain adalah pelaksanaan PATEN atau dikenal dengan Pelayanan Administrasi Terpadu Kecamatan, telah terimplementasi sebanyak 316 hingga akhir tahun 2020. Pencapaian kinerjanya telah mencapai $100 \%$. PATEN sendiri merupakan bagian dari program peningkatan pengawasan dan pengendalian penanaman modal dengan indikator kinerja program yang masuk kedalam jumlah perusahaan yang ditinjau penggunaan dan perizinannya.

\section{Sistem pengendalian $(\mathrm{X} 8)$}

Nilai koefisien X8 sebesar 0,506 menunjukkan bahwa apabila nilai sistem pengendalian (X8) bertambah satu maka tingkat investasi (Y) bertambah 0,506 dengan asumsi X1, X2, X3, X4, X5, X6, dan X7 tetap. Untuk hasil pengujian hipotesis untuk sistem pengendalian (X8) terhadap tingkat investasi $(\mathrm{Y})$ diperoleh nilai $\mathrm{p}$ (Sig.) $=$ 0,042. Nilai tersebut kurang dari 0,05 sehingga H0 ditolak dan H1 diterima. Dengan demikian dapat disimpulkan bahwa terdapat pengaruh sistem pengendalian (X8) terhadap tingkat investasi (Y). hasil tersebut menunjukan bahwa pengendalian untuk mengatur dan mencegah apabila kemungkinan-kemungkinan adanya penyimpangan dalam pelaksanaan suatu program atau kegiatan, sehingga tujuan Dinas PMPTSP Kabupaten Pangkep dapat tercapai.

Perihal tersebut pula sejalan dengan Peraturan Menteri Dalam Negara No 24 Tahun 2006 tentang Pedoman Penyelenggaraan Pelayanan Terpadu Satu Pintu, serta Peraturan Menteri Dalam Negara No 20 Tahun 2008 tentang Pedoman Organisasi serta Tatakerja Unit Pelayanan Perijinan Terpadu di Wilayah yang berpedoman pada Peraturan Pemerintah No 41 Tahun 2007. Tentang Organisasi Fitur Wilayah, hingga dibentuklah fitur wilayah penyelenggara pelayanan terpadu satu pintu di daerah- wilayah Indonesia, baik Provinsi ataupun Kabupaten/ Kota.

Dilain pihak dalam Undang- Undang No 25 Tahun 2007 tentang Penanaman Modal, spesialnya Pasal 25 serta Pasal 26, diataranya melaporkan, kalau industri penanaman modal yang hendak melaksanakan aktivitas usaha harus mendapatkan izin cocok dengan syarat peraturan perundang- undangan dari lembaga yang mempunyai kewenangan, lewat pelayanan terpadu satu pintu( PTSP). Pelayanan Terpadu Satu Pintu( PTSP), merupakan aktivitas penyelenggaraan sesuatu Perizinan serta Nonperizinan yang menemukan pendelegasian ataupun pelimpahan wewenang dari lembaga ataupun lembaga yang mempunyai kewenangan perizinan serta non perizinan yang proses pengelolaannya diawali dari sesi permohonan hingga dengan sesi terbitnya dokumen yang dicoba dalam satu tempat, sehingga dengan PTSP ini efektivita pelayanan bisa ditingkatkan. 


\section{Maldun)}

Dari Koefisien regresi dari variabel-variabel independen tersebut bernilai positif, hal ini menunjukkan bahwa variabel-variabel independen tersebut berpengaruh positif terhadap variabel dependen.

Hasil pengujian hipotesis menunjukkan bahwa masing-masing variabel independen yang terdiri dari kejelasan tujuan (X1), kejelasan strategi (X2), proses analisis kebijakan (X3), perencanaan (X4), penyusunan program (X5), sarana dan prasarana (X6), sistem pengawasan (X7), dan sistem pengendalian (X8) secara parsial berpengaruh signifikan terhadap tingkat investasi (Y). Disamping itu kedelapan variabel bebas tersebut juga berpengaruh secara simultan (bersama-sama) terhadap tingkat investasi di Dinas PMPTSP Kabupaten Pangkep.

Variabel independen yang terdiri dari kejelasan tujuan, kejelasan strategi, proses analisis kebijakan, perencanaan, penyusunan program, sarana dan prasarana, sistem pengawasan, dan sistem pengendalian merupakan indikator untuk mengukur efektivitas suatu pelayanan publik yang dikemukakan oleh James L. Gibson dalam A. Kurniawan (2005:107). Adanya pengaruh positif yang signifikan masing-masing variabel tersebut terhadap tingkat investasi di Dinas PMPTSP Kabupaten Pangkep mengindikasikan bahwa setiap variabel independen berkontribusi positif terhadap tingkat investasi di Dinas PMPTSP Kabupaten Pangkep. Hal ini menunjukkan bahwa kualitas pelayanan yang diukur dari indikator kejelasan tujuan, kejelasan strategi, proses analisis kebijakan, perencanaan, penyusunan program, sarana dan prasarana, sistem pengawasan, dan sistem pengendalian efektif dalam menambah atau meningkatkan investasi di Dinas PMPTSP Kabupaten Pangkep.

Hasil penelitian ini sejalan dengan hasil penelitian Imelda Febliany, Nur Fitriyah, Enos Paselle dengan judul jurnal Efektivitas Pelayanan Terpadu Satu Pintu Terhadap Penyerapan Investasi Di Kalimantan Timur (Studi Pada Badan Perijinan Dan Penanaman Modal Daerah Provinsi Kalimantan Timur). Kesimpulan aspek pendukung serta Penghambat Daya guna Pelayanan Satu Pintu( PTSP) ialah terdapatnya pelayanan yang baik dari petugas, terdapatnya sarana yang lengkap serta modern, kepedulian warga/ pengusaha terhadap data ataupun inovasi baru yang diberikan Badan Perizinan dan serta Penanaman Modal Wilayah( BKPMD) dan kenaikan teknologi data yang berkaitan dengan akses tentang prosedur pelayanan terpadu. Sebaliknya Aspek penghambat, yang nampak merupakan cuma pada minimnya kelengkapan.

\section{Tingkat Investasi}

Bersumber pada Peraturan Presiden Republik Indonesia No 91 Tahun 2017 tentang percepatan penerapan berupaya, pasal( 1) poin( 1) ialah Satuan Tugas merupakan satuan tugas yang dibangun buat tingkatkan pelayanan, pengawalan, penyelesaian hambatan, penyederhanaan, serta pengembangan sistem online dalam rangka percepatan penerapan perizinan berupaya tercantum untuk usaha mikro, kecil, serta menengah sehabis memperoleh persetujuan penanaman modal. Berikutnya poin( 5) Pelakon Usaha merupakan orang perseorangan ataupun tubuh usaha yang mengajukan permohonan penerbitan Perizinan Berupaya buat aktivitas berupaya, serta poin( 6) Standar Pelayanan merupakan tolok ukur yang dipergunakan selaku pedoman penyelenggaraan pelayanan oleh pemerintah yang muat syarat menimpa pelakon usaha yang berhak, persyaratan, prosedur penyelesaian, serta jangka waktu penyelesaian.

Bersumber pada hasil riset hingga periset menganalisis kalau Dinas Penanaman Modal serta Pelayanan Terpadu Satu Pintu Kabupaten pangkep bisa meningatkan investasi selaku berikut: Tingkatkan nilai investasi lewat promosi, penyempurnaan peraturan serta pengendalian penerapan penanaman modal dengan menggunakan sistem teknologi data; Tingkatkan mutu pelayanan perizinan lewat penciptaan inovasi layanan berbasis sistem teknologi data; Mengelola pengaduan warga dengan berbasis quick response; Melaksanakan pembinaan serta kenaikan kapasitas aparatur Dinas Penanaman Modal serta Pelayanan Terpadu Satu Pintu( DPMPTSP) cocok kompetensi; Tingkatkan mutu fasilitas serta prasarana pelayanan yang mencukupi serta profesional. Buat tingkatkan kinerja dari Dinas Penanaman Modal serta Pelayanan Terpadu Satu Pintu( DPMPTSP) Kabupaten Pangkep dalam strategis yang jadi fokus Dinas PMPTSP mencakup: Tingkatkan investasi DKI Jakarta dengan menghasilkan hawa investasi serta kemudahan berbisnis. Tingkatkan pelayanan publik baik layanan perizinan serta non perizinan dengan meningkatkan system berbasis teknologi informasi.

Hasil analisis regresi linear multipel diperoleh persamaan regresi yaitu: $Y=2,411+0,597 X_{1}+$ $0,917 X_{2}+0,488 X_{3}+0,676 X_{4}+0,719 X_{5}+0,837 X_{6}+$ $0,493 X_{7}+0,506 X_{8}$. Persamaan regresi tersebut mengandung konstanta sebesar 2,411. Nilai tersebut menunjukkan besarnya variabel tingkat investasi (Y) tanpa memperhatikan variabel-variabel independen. Dengan kata lain apabila nilai variabel-variabel independen sama dengan nol maka tingkat investasi tetap memiliki nilai sebesar 2,411.

Hasil riset ini sejalan dengan hasil riset Meter. Budi Mulyadi dengan judul riset pelayanan perizinan terpadu dalam tingkatkan investasi serta perkembangan UMKM. Kesimpulan Perizinan ialah suatu instrument yang dipunyai pemerintah buat mengatur warga, paling utama dalam mengatur pada kegiatan ekonomi serta sosial. Buat tingkatkan perekonomian warga serta tingkatkan hawa investasi pemerintah wajib mengupayakan pelayanan perizinan yang lebih gampang, murah serta kilat. Sokongan bayaran yang murah, gampang serta kilat hendak menarik para pengusaha serta investor buat menginvestasikan usahanya di wilayah tersebut. Pemerintah mengupayakan supaya segala pemerintah wilayah bisa membagikan pelayanan perizinan terpadu supaya tingkatkan hawa investasi serta penanaman modal. Apalagi membagikan sanksi untuk wilayah yang belum 
mempraktikkan sistem pelayanan perizinan terpadu kepada warga.

\section{KESIMPULAN DAN SARAN}

Pengaruh secara parsial variabel independen (kualitas pelayanan) terhadap variabel dependen (tingkat investasi) di Dinas PMPTSP Kabupaten Pangkep bahwa terdapat kualitas pelayanan Dinas PMPTSP dalam meningkatkan investasi di Kabupaten Pangkep seperti kejelasan tujuan, kejelasan strategi, proses analisis kebijakan, perencanaan, penyusunan program, sarana dan prasarana, sistem pengawasan, dan sistem pengendalian. Pengaruh secara simultan variabel independen (kualitas pelayanan) terhadap variabel dependen (tingkat investasi) di Dinas PMPTSP Kabupaten Pangkep terdapat kualitas pelayanan Dinas PMPTSP dalam meningkatkan investasi di Kabupaten Pangkep seperti kejelasan tujuan, kejelasan strategi, proses analisis kebijakan, perencanaan, penyusunan program, sarana dan prasarana, sistem pengawasan, dan sistem pengendalian

Pemerintah daerah setempat khususnya pemerintah Kabupaten Pangkep hendaknya tetap memberikan kontrol yang intens terhadap pelayanan di Dinas PMPTSP agar efektivitas pelayanan di dinas tersebut dapat terjaga atau bahkan dapat ditingkatkan. Penelitian lebih lanjut mengenai efektivitas pelayanan dan kontribusinya terhadap tingkat investasi perlu dilakukan pada objek penelitian yang berbeda untuk menambah kredibilitas hasil penelitian ini

\section{DAFTAR PUSTAKA}

Alkadri, M. J., Jamal, M., \& Dyastari, L. (2019). Efektivitas Pelayanan Dinas Penanaman Modal dan Pelayanan Terpadu Satu Pintu dalam Pembuatan Surat Izin Usaha Perdagangan (SIUP) di Kabupaten Paser. ejournal.ipfisip-unmul.ac.id (C) Copyright 2019 eJournal Ilmu Pemerintahan, 2019, 7 (2): 675686.

Anggela, L. (2013). Efektifitas Kinerja Pegawai Pada Badan Pelayanan Terpadu Perizinan dan Penanaman Modal (BPTP2M) Kabupaten Rokan Hulu Provinsi Riau. Universitas Islam Negeri Sultan Syarif Kasim Riau.

Anggraini, T. (2019). Inovasi Birokrasi Pelayanan Publik di Dinas Penanaman Modal dan Pelayanan Terpadu Satu Pintu (DPMPTSP) di Kabupaten Musi Banyuasin Studi Kasus: (Siap Antar Jemput Izin Mudah Berbantuan (SAJI MUBA)). Politeia: Jurnal Ilmu Politik. https://doi.org/10.32734/politeia.v11i2.1122

Arya, F. A. (2019). “AJEP”: Strategi Inovasi Dinas Penanaman Modal Pelayanan Terpadu dan Perindustrian Kabupaten Padang Pariaman dalam Pelayanan Publik. Jurnal Administrasi Dan Kebijakan Publik.

https://doi.org/10.25077/jakp.3.3.239-249.2018
Boediono. (2008). Dimensi Ekonomi Politik Pembangunan Indonesia. Jurnal Keuangan Publik.

Deliarnov. (1995). Perkembangan pemikiran ekonomi. Raja Grafindo Persada.

Eduardus Tendelilin. (2001). Analisis Investasi dan Manajemen Portofolio, Edisi I, cet. I. Yogyakarta, BPFE. https://doi.org/10.21082/jae.v25n1.2007.5583

Eka Parmawati, A. S. (2008). Kausalitas Penerimaan, Belanja dan PDRB Kabupaten/Kota di Indonesia (Studi Kasus Periode 2001- 2008). Universitas Diponegoro.

Fabozzi, F. J., \& Grant, J. L. (2000). Value-based metrics: Foundations and practice (Vol.67). John Wiley \& Sons.

Febliany, I., Fitriyah, N., \& Paselle, E. (2017). Efektivitas Pelayanan Terpadu Satu Pintu Terhadap Penyerapan Investasi di Kalimantan Timur (Studi pada Badan Perijinan dan Penanaman Modal Daerah Provinsi Kalimantan Timur). Jurnal Administrative Reform (JAR), 2(3), 410-420.

Ghozali, I. (2011). Aplikasi Analisi Multivariate dengan Program SPSS. Edisi Kelima Semarang: Bandan Penerbitan Universitas Diponegoro.

Halim, A. (2005). Analisis Investasi. Jakarta: Salemba Empat.

Indonesia, R. (2007). Undang-Undang No. 25 Tahun 2007 Tentang Penanaman Modal. Jakarta: Sekretariat Negara.

Ismayanti, L. (2015). Efektivitas Penyelenggaraan Pelayanan Terpadu Satu Pintu di Kabupaten Malang. JISIP: Jurnal Ilmu Sosial Dan Ilmu Politik, 4(2).

James, L. G., Ivancevich, J. M., Donnelly, J. H., \& Konopaske, R. (2009). Organization: Behavior, Structure, Processes. In McGraw-Hill, Irvin. 